\title{
Breve consideración sobre aspectos éticos y morales de la ciencia.
}

\author{
Carta al Editor
}

Jesús Quintanilla-Osorio.

Coordinación de Regulación Sanitaria, Servicios Estatales de Salud en Quintana Roo. Chetumal, Quintana Roo, México.

¿Cuales son los límites éticos y morales de la ciencia? ¿Está permitido al hombre, violar todos los secretos de la naturaleza en nombre de los avances científicos?

Sin pretender ser axiomáticos y entendiendo que son necesarios los desarrollos de nuevas tecnologías así como las investigaciones acuciosas que permitan una mejoría notable en las condiciones de vida de los seres humanos, es evidente que tampoco es conveniente traspasar sin consideraciones de ninguna clase, el umbral que esconde secretos que todavía nos están vedados por nuestro propio bien, y tal vez sea mejor dejarlos así, como es el caso del genoma humano.

Dadas las tendencias humanas en cuanto a conducta criminal y la potencialidad destructiva que la historia nos ha demostrado en casos como el de Adolfo Hitler durante la dictadura nazi, que utilizó como conejillos de indias a personas consideradas marginales por su origen religioso o por ser discapacitados, la posibilidad nada remota de que fueran manipulados tales conocimientos en nombre de grupos de poder económico o político para controlar a una gran parte de la población, debe alertarnos sobre las conveniencias de permitir la absoluta libertad a la ciencia.

Recordemos que John Mill, señaló que, "si toda la humanidad, menos una persona, fuera de una misma opinión, y esta persona fuera de opinión contraria, la humanidad sería tan injusta impidiendo que hablase, como ella misma lo sería si teniendo poder bastante impidiera que hablara la humanidad" (1), y en ese contexto, el poder conferido a los científicos, dados sus conocimientos, los sitúan por encima del común de los mortales, como el mismo Charles Darwin lo reconocía en su "Autobiografía", "creo que estoy por encima del común de las gentes en lo que se refiere a la percepción de las cosas que escapan fácilmente a nuestra atención, y a su atenta observación" (2). Sin embargo, esto no constituye una desventaja, si se mantuviera la sensatez que el mismo padre de "El origen de las especies" asume con modestia al señalar que poseía "cualidades ordinarias", cuando su pensamiento

Solicitud de sobretiros: T.V.S. Jesús Quintanilla-Osorio, Calle Tlaxcalaltongo 250 entrre Carranza y San Salvador, Col. V. Carranza, C.P. 77000 , Chetumal, Quintana Roo, México. 


\section{J Quintanilla-Osorio.}

cambió toda la concepción aceptada hasta entonces como un axioma inamovible.

Pero no ha sucedido así siempre y los ejemplos sobre el uso perverso de los avances de la ciencia, significaron un amanecer de fuego para la gente de Hiroshima, aquel fatídico 6 de Agosto de 1945, como un recordatorio de la insensatez humana. Por esto, el eminente biólogo Vandel citado por Jean Rostand en uno de sus "Ensayos sobre lo humano", dice que "un hombre no es uno de los representantes intercambiables de una especie, si no una persona diferente a otra, y por consiguiente irreemplazable. Suprimir un solo hombre es, más o menos, empobrecer la humanidad de una manera segura" (3).

Y si no existen barreras éticas o morales que impidan penetrar los linderos de la vida, el riesgo de sufrir una decepción para el homo intelectus de nuestro tiempo -acostumbrado a los vuelos trasatlánticos y los enlaces satelitales a través de un teléfono celular, pero amante de la privacidad y defensor de los derechos humanos-, puede revertir nuestro propio desarrollo como seres pensantes. La ciencia, entonces, debe servir al hombre y elevarlo por encima de los animales, sin aprovecharse rapazmente de ellos porque somos una cadena concatenada, donde cada eslabón es único, siempre y cuando se marquen límites como el que el biólogo Darlington dice al señalar que "la individualidad humana debería ser el fundamento de toda legislación" (3). De otra manera, estaremos apostando a nuestra propia destrucción.

Palabras clave: Ética científica.

\section{REFERENCIAS.}

1.- Stuart Mill, John. De la libertad de pensamiento y discusión. 1ª edición, México: Alianza Editorial; 1994.

2.- Darwin Ch. Autobiografía. $1^{a}$ edición. México: Alianza Editorial; 1994.

3.- Rostand, J. Ensayos sobre lo humano. $1^{\text {a }}$ edición, México: Alianza Editorial; 1994.

\section{Revista Biomédica}

